Monika Pettersen-Sobczyk*

\title{
MAKRO- I MIKROOTOCZENIE BANKÓW KOMERCYJNYCH W POLSCE - GŁÓWNE TENDENCJE I CZYNNIKI
}

\section{Wprowadzenie}

Analiza otoczenia banków komercyjnych przeprowadzona w kompleksowy sposób ma za zadanie identyfikację szans oraz zagrożeń, jakie niesie za sobą otoczenie, w którym przedsiębiorstwo bankowe funkcjonuje. Aby można było ocenić analizę jako kompleksową, powinny jej zostać poddane najważniejsze czynniki determinujące funkcjonowanie banków. Celem artykułu jest wskazanie głównych tendencji i czynników zmian w makro- oraz mikrootoczeniu banków komercyjnych w Polsce.

\section{Metodyka badawcza}

Na potrzeby realizacji celu artykułu wykorzystano krytyczną analizę literatury, analizę danych źródłowych (Główny Urząd Statystyczny, Urząd Komisji Nadzoru Finansowego, Narodowy Bank Polski) oraz analizę porównawczą. Zakres czasowy analizy to lata 2000-2013. Analizie zostały poddane elementy makro- oraz mikrootoczenia banków komercyjnych w Polsce.

\section{Istota otoczenia banku komercyjnego}

Współczesne systemy bankowe podlegają silnemu oddziaływaniu zarówno otoczenia krajowego, jak również międzynarodowego. Czynniki zewnętrzne wywierają coraz silniejszy wpływ na konstrukcję narodowych systemów bankowych, jednak

* Uniwersytet Szczeciński, Wydział Zarządzania i Ekonomiki Usług. 
mimo to systemy bankowe funkcjonujące w poszczególnych krajach o gospodarce rynkowej często bardzo się od siebie różnią. Wynika to $\mathrm{z}$ faktu, iż ukształtowały się w specyficznych warunkach politycznych i gospodarczych, które miały wpływ na treść i charakter bankowych regulacji prawnych oraz na działanie czynników związanych $\mathrm{z}$ tradycją systemów finansowych ${ }^{2}$. W związku z tym można stwierdzić, że otoczenie banków komercyjnych determinuje ich działania. To, w jakim otoczeniu funkcjonują banki, ma wpływ na wiele czynników związanych z ich działalnością. Ponadto określenie otoczenia, zarówno makro, jak również mikro, jest niezbędnym elementem konstruowania strategii każdego przedsiębiorstwa działającego na rynku.

Pod pojęciem otoczenia należy rozumieć wszystkie zjawiska, procesy, podmioty, które nie wchodzą w skład przedsiębiorstwa, ale są z nim związane przez proces wzajemnego oddziaływania. Tym samym otoczenie stwarza szanse bądź zagrożenia dla jego dalszego przetrwania lub rozwoju. Kompatybilny rozwój z otoczeniem i dynamiczne sprzężenie pozwalają budować wartość przedsiębiorstwa bankowego, zwłaszcza jego wartość rynkową. Ze względu na charakter związków między otoczeniem a przedsiębiorstwem oraz ze względu na powstające skutki rozróżnić można:

- makrootoczenie (otoczenie dalsze, ogólne) - zjawiska, procesy i podmioty, które oddziałują na przedsiębiorstwo pośrednio, obiektywnie, stwarzając ramy działalności,

- mikrootoczenie (otoczenie bezpośrednie, zadaniowe, społeczne) - zjawiska, procesy i podmioty, które oddziałują bezpośrednio na przedsiębiorstwo i są przedmiotem jego oddziaływań ${ }^{3}$.

Makrootoczenie to zbiór warunków działania wszystkich przedsiębiorstw funkcjonujących w danym miejscu i czasie. Z miejscem i czasem działania przedsiębiorstwa wiąże się nie tylko klimat, sytuacja gospodarcza kraju oraz regionu, stan infrastruktury, a także prawo, ale również m.in. upodobania ludności, normy kulturowe, które wpływają na zachowania konsumentów. Dla ułatwienia przeprowadzania analizy makrootoczenia czynniki te można podzielić na jednorodne segmenty (tabela 1) i w każdym z nich poszukiwać szans oraz zagrożeń dla przedsiębiorstwa ${ }^{4}$. Cechą makrootoczenia jest silne oddziaływanie na możliwości funkcjonowania i rozwoju podmiotów gospodarczych, które nie są w stanie zmienić tych warunków. Dla banków warunki kreowane przez makrootoczenie są datami, zjawiskami, które należy znać i antycypować, ale nie należy poddawać się ich oddziaływaniu. Przedsiębiorstwa

2 System finansowy w Polsce, red. B. Pietrzak, Z. Polański, B. Woźniak, Wydawnictwo Naukowe PWN, Warszawa 2003, s. 75.

3 E. Urbanowska-Sojkin, P. Banaszak, H. Witczak, Zarzadzanie strategiczne przedsiębiorstwem, PWE, Warszawa 2007, s. 104-105.

4 M. Romanowska, Planowanie strategiczne w przedsiębiorstwie, PWE, Warszawa 2009, s. 33. 
mogą jedynie odbierać sygnały pochodzące z otoczenia i odczytywać je jako szanse lub zagrożenia, bez możliwości aktywnego wpływania na nie.

Makrootoczenie banków komercyjnych w Polsce stanowi całokształt czynników, wśród których wymienia się: otoczenie ekonomiczne, polityczno-prawne, technologiczno-informacyjne, społeczno-kulturowe oraz geograficzne. Zakres poszczególnych czynników przedstawia tabela 1 .

\section{Tabela 1. Elementy makrootoczenia banku komercyjnego}

\begin{tabular}{|c|c|}
\hline Otoczenie banku komercyjnego & Elementy makrootoczenia banku komercyjnego \\
\hline Ekonomiczne & $\begin{array}{l}\text { - stopa inflacji } \\
\text { - kursy wymiany walut } \\
\text { - stopa wzrostu PKB } \\
\text { - stopy procentowe } \\
\text { - stopa bezrobocia } \\
\text { - stopa podatkowa (ulgi, zwolnienia) } \\
\text { - dochody ludności } \\
\text { - infrastruktura (drogi, hotele, transport) } \\
\text { - koszty energii (dostęp do tańszych źródeł) } \\
\text { - dostęp do kwalifikowanej siły roboczej } \\
\text { - elastyczność cen } \\
\text { - cykle koniunkturalne }\end{array}$ \\
\hline Polityczno-prawne & $\begin{array}{l}\text { - polityka zagraniczna i wewnętrzna rządu } \\
\text { - przepisy celne } \\
\text { - przepisy ekologiczne } \\
\text { - przepisy antymonopolowe } \\
\text { - przepisy antydumpingowe } \\
\text { - etyka reklamy } \\
\text { - przepisy w zakresie zatrudniania i zwalniania pracowników } \\
\text { - przepisy w zakresie płacy minimalnej } \\
\text { - monopol chroniony przez państwo } \\
\text { - przepisy podatkowe } \\
\text { - przepisy ochrony patentów, licencji } \\
\text { - przepisy kontroli organów państwowych (UKS, US, NIK, SANEPID, PIP, PIH, UC) }\end{array}$ \\
\hline Technologiczno-informacyjne & $\begin{array}{l}\text { - tempo zmian technologicznych } \\
\text { - starzenie się i umieranie sektorów } \\
\text { - wyłanianie się nowych sektorów } \\
\text { - faza rozwoju sektora } \\
\text { - liderzy w technologii }\end{array}$ \\
\hline Społeczno-kulturowe & $\begin{array}{l}\text { - demografia (wyże, wiek, płeć, małżeństwa, migracje, liczba dzieci) } \\
\text { - zmiana wartości życia (hedonizm, liberalizm, ultraindywidualizm, relatywizm) } \\
\text { - etos pracy } \\
\text { - rozpad rodziny }\end{array}$ \\
\hline Geograficzne & $\begin{array}{l}\text { - zakres terytorialny działalności banku } \\
\text { - kraj pochodzenia banku } \\
\text { - siedziby placówek bankowych }\end{array}$ \\
\hline
\end{tabular}

Źródło: Opracowanie własne na podstawie Z. Drążek, B. Niemczynowicz, Zarządzanie strategiczne przedsiębiorstwem, PWE, Warszawa 2003, s. 107; A. Stabryła, Zarządzanie strategiczne w teorii i praktyce firmy, Wydawnictwo Naukowe PWN, Warszawa-Kraków 2000, s. 146; M. Romanowska, Planowanie strategiczne w przedsiębiorstwie, PWE, Warszawa 2009, s. 33-35; E. Urbanowska-Sojkin, P. Banaszak, H. Witczak, Zarządzanie strategiczne przedsiębiorstwem, PWE, Warszawa 2007, s. 103-113. 
Do uniwersalnych narzędzi stosowanych $\mathrm{w}$ analizie makrootoczenia należy zaliczyć: opis statystyczny, prognozy, opinie. Korzystanie z tych instrumentów ułatwia wykonanie analizy, czyniąc ją wszechstronną i miarodajną. Należy korzystać z wyników statystycznych badań ekonomicznych, które zwłaszcza w skali makrogospodarczej są istotnym źródłem informacji o sytuacji rynkowej, produkcyjnej, społecznej ${ }^{5}$.

Mikrootoczenie nazywane jest również otoczeniem bliższym, sektorowym lub też konkurencyjnym. W skład mikrootoczenia wchodzą wszystkie podmioty gospodarcze, które mają z bankiem powiązania kooperacyjne lub korporacyjne. Najważniejszymi czynnikami mikrootoczenia są, zdaniem Portera, także siły przetargowe dostawców, odbiorców oraz groźba pojawienia się nowych produktów i substytutów (konkurencja potencjalna i substytucyjna). Cechą mikrootoczenia jest to, że pomiędzy poszczególnymi jego podmiotami występują sprzężenia zwrotne o charakterze ekonomicznym ${ }^{6}$.

\section{Główne czynniki i tendencje w makrootoczeniu banków komercyjnych w Polsce}

Przedsiębiorstwa bankowe muszą nie tylko reagować na to, co się dzieje, ale też antycypować stany przyszłe i wystarczająco wcześnie się do nich przygotować. $\mathrm{Na}$ rynku polskim przyszłe zmiany będą się koncentrowały głównie wokół konsekwencji zjawisk demograficznych, zmian w sytuacji ekonomicznej i politycznej krajów Unii Europejskiej, Stanów Zjednoczonych, Chin oraz Rosji. Zmiany w sektorze bankowym będą następowały m.in. pod wpływem przemian w porządku formalno prawnym Polski i krajów Unii Europejskiej ${ }^{7}$, zmian technologicznych, a także przemian kulturowych, zwykle trudniej uchwytnych, mających względnie dużą dynamikę i skutkujących zmianą modelu życia, postaw czy oczekiwań. Rozważając kwestie związane $\mathrm{z}$ uwarunkowaniami funkcjonowania instytucji finansowych w Polsce, i nie tylko, należy brać pod uwagę konglomerat zróżnicowanych czynników. Ich identyfikacja, analiza i monitorowanie pozwalają na podejmowanie przez instytucje finansowe adekwatnych działań oraz inicjatyw. Należy zwrócić również uwagę na wzajemne

5 A. Stabryła, op.cit., s. 139.

6 Z. Drążek, B. Niemczynowicz, Zarządzanie strategiczne przedsiębiorstwem, Polskie Wydawnictwo Ekonomiczne, Warszawa 2003, s. 124.

7 Zob. R. Kałużny, Ocena funkcjonowania banków w świetle zmieniających się regulacji prawnych, w: „Zeszyty Naukowe Uniwersytetu Szczecińskiego” 2014, nr 802; „Finanse, Rynki Finansowe, Ubezpieczenia" 2014, nr 65, red. D. Zarzecki, Wydawnictwo Naukowe Uniwersytetu Szczecińskiego, s. 499-510. 
zależności i oddziaływania pomiędzy poszczególnymi czynnikami ${ }^{8}$ Wybrane uwarunkowania funkcjonowania banków komercyjnych w Polsce ${ }^{9}$ to:

- uwarunkowania ekonomiczne - wśród których wymienia się: zmiany gospodarcze, zmiany cen na rynkach, występowanie okresów bessy i hossy, kryzysy gospodarcze. Uwarunkowania ekonomiczne wynikają głównie ze zmieniających się realiów gospodarczych i w związku z tym najczęściej są bodźcem do przeprowadzania zmian czy nowelizacji aktów prawnych. W ten sposób wyznaczają nowe kierunki działania banków lub też bezpośrednio wpływają na sposób ich zarządzania i organizacji. Przykładem wpływu uwarunkowań ekonomicznych na działanie banków był kryzys finansowy lat 2007/2008+. Wybuch kryzysu na arenie międzynarodowej miał swoje konsekwencje dla podmiotów rynku finansowego, w tym również dla polskiego sektora bankowego. Konsekwencją było m.in. zdecydowane zaostrzenie procedur w zakresie analityki wewnętrznej banku, oceny zdolności kredytowej klientów, zarządzania ryzykiem, a także w zakresie transparentności działań podejmowanych przez banki. Kryzys postawił też przed bankami pytanie o zakres i etyczny wymiar ich działalności. Tabela 2 przedstawia wybrane wskaźniki ekonomiczne w latach 2000-2013 w Polsce. Analiza dynamiki zmian poszczególnych wskaźników umożliwia sformułowanie opinii, że sytuacja na rynku finansowym w ostatnich latach była względnie stabilna i sprzyjająca rozwojowi sektora bankowego,

- uwarunkowania polityczne - zmiany w polityce pieniężnej kraju, zmiany w polityce pieniężnej Europejskiego Banku Centralnego, zmiany w polityce fiskalnej. Z punktu widzenia działalności banków istotne są uwarunkowania wynikające $\mathrm{z}$ charakteru polityki uprawianej przez państwo, w tym głównie polityki pieniężnej, ale także np. polityki fiskalnej. Można tutaj brać pod uwagę wszelkie czynniki spowodowane działaniem tak zwanej polityki gospodarczej, która stanowi sposób świadomego oddziaływania państwa na gospodarkę za pomocą określonych narzędzi (instrumentów) i środków dla osiągnięcia celów założonych przez podmioty polityki gospodarczej. Biorąc pod uwagę politykę pieniężną i jej sposób oddziaływania na funkcjonowanie banków, kluczowe znaczenie ma przede wszystkim jej cel, jakim jest ograniczanie inflacji w warunkach wzrostu gospodarczego, odzwierciedlonego m.in. rosnącym produktem krajowym brutto. Celowi temu podporządkowane są posunięcia w zakresie polityki stóp procentowych, polityki kursów walutowych oraz polityki podaży pieniądza. Z punktu

8 Zarzadzanie instytucjami kredytowymi, red. A. Gospodarowicz, A. Nosowski, CH Beck, Warszawa 2012, s. 22-23.

9 Ibidem, s. 22-35. 
widzenia banków najważniejsze jest przyjmowanie, w ramach realizowanej polityki, właściwych przesłanek systemowych do kształtowania się takiego poziomu stóp procentowych, który: zwiększa skłonność do oszczędzania w walucie krajowej, zapewnia realny przyrost kredytów dla gospodarki, umożliwia bankom racjonalizowanie podejścia $\mathrm{w}$ ramach wyznaczania swojej marży poprzez określanie oprocentowanie depozytów i kredytów. Obecnie stopy procentowe banku centralnego utrzymują się na rekordowo niskim poziomie, co obrazuje tabela 2. Polityka fiskalna i polityka pieniężna wspólnie wpływają na kształtowanie się równowagi makroekonomicznej, gdyż działania w obszarze polityki pieniężnej realizowane przez banki centralne rodzą konsekwencje dla warunków prowadzenia polityki fiskalnej rządów. Polityka fiskalna kształtuje również warunki funkcjonowania banków centralnych,

Tabela 2. Wybrane wskaźniki ekonomiczne w latach 2000-2013 w Polsce

\begin{tabular}{|c|c|c|c|c|c|c|c|}
\hline Rok & $\begin{array}{c}\text { PKB } \\
\text { (w mln PLN) }\end{array}$ & $\begin{array}{c}\text { Wskaźnik cen } \\
\text { towarów i usług } \\
\text { konsumpcyjnych } \\
\text { przy } \\
\text { podstawie rok } \\
\text { poprzedni }=100\end{array}$ & $\begin{array}{c}\text { Bezrobocie } \\
\text { ogółem } \\
\text { (stan } \\
\text { na koniec } \\
\text { roku) }\end{array}$ & $\begin{array}{c}\text { Stopa } \\
\text { procentowa } \\
\text { redyskonta } \\
\text { weksli }\end{array}$ & $\begin{array}{c}\text { Stopa } \\
\text { procentowa } \\
\text { kredytu } \\
\text { lombardowego }\end{array}$ & $\begin{array}{c}\text { Stopa } \\
\text { referencyjna }\end{array}$ & $\begin{array}{c}\text { Kurs EUR } \\
\text { (oficjalny } \\
\text { NBP) }\end{array}$ \\
\hline 2000 & 744378 & 110,1 & 15,1 & 21,50 & 23,00 & 19,00 & 4,0110 \\
\hline 2001 & 779554 & 105,5 & 17,5 & 14,00 & 15,50 & 11,50 & 3,6685 \\
\hline 2002 & 808578 & 101,9 & 18,0 & 7,50 & 8,75 & 6,75 & 3,8557 \\
\hline 2003 & 843156 & 100,8 & 20,0 & 5,75 & 6,75 & 5,25 & 4,3978 \\
\hline 2004 & 924538 & 103,5 & 19,0 & 7,00 & 8,00 & 6,50 & 4,5340 \\
\hline 2005 & 983302 & 102,1 & 17,6 & 4,75 & 6,00 & 4,50 & 4,0254 \\
\hline 2006 & 1060031 & 101,0 & 14,8 & 4,25 & 5,50 & 4,00 & 3,8951 \\
\hline 2007 & 1176737 & 102,5 & 11,2 & 5,25 & 6,50 & 5,00 & 3,7829 \\
\hline 2008 & 1275508 & 104,2 & 9,5 & 5,25 & 6,50 & 5,00 & 3,5166 \\
\hline 2009 & 1344505 & 103,5 & 12,1 & 3,75 & 5,00 & 3,50 & 4,3273 \\
\hline 2010 & 1416585 & 102,6 & 12,4 & 3,75 & 5,00 & 3,50 & 3,9946 \\
\hline 2011 & 1528127 & 104,3 & 12,5 & 4,75 & 6,00 & 4,50 & 4,1198 \\
\hline 2012 & 1596378 & 103,7 & 13,4 & 4,50 & 5,75 & 4,25 & 4,1850 \\
\hline 2013 & 1635746 & 100,9 & 13,4 & 2,75 & 4,00 & 2,50 & 4,1975 \\
\hline
\end{tabular}

Źródło: Opracowanie własne na podstawie danych GUS i NBP.

- uwarunkowania społeczne - zmiany demograficzne, zmiany w zakresie potrzeb i oczekiwań, starzenie się społeczeństw, zmiany w stylu życia. Uwarunkowania społeczne mają istotny wpływ na sposób działania banków poprzez kształtowanie modeli biznesowych oraz strategii współczesnych banków. W tym kontekście 
szczególną uwagę należy zwrócić na zmiany demograficzne, a zwłaszcza na starzenie się społeczeństw i jego implikacje finansowe - zarówno w wymiarze danego kraju, jak i w wymiarze indywidualnym. Długość życia sukcesywnie się zwiększa. Zjawisko to nie jest obojętne dla funkcjonowania banków. Na początku XX w. socjologowie wyodrębniali trzy grupy społeczne (dzieci, dorosłych i osoby starsze), natomiast badania z 2008 r. pokazały, że można zidentyfikować już sześć grup społecznych (dzieci, dorastający, dorośli, lifestyle - dorośli w wieku 55-65 lat, pracujący - dysponujący czasem oraz środkami na prowadzenie aktywnego życia, emeryci i seniorzy). Taki stan rzeczy powoduje, że banki zmuszone są dopasowywać swoją ofertę do potrzeb poszczególnych grup społecznych.

Tabela 3. Wybrane wskaźniki demograficzne w Polsce w latach 2000-2013

\begin{tabular}{|c|c|c|c|c|c|c|c|}
\cline { 3 - 8 } \multicolumn{2}{l|}{} & \multicolumn{4}{c|}{ Ludność w wieku (w \% ogółu ludności) } & \multicolumn{2}{c|}{$\begin{array}{c}\text { Średnia długość życia } \\
\text { (w latach) }\end{array}$} \\
\hline Rok & $\begin{array}{c}\text { Ludność } \\
\text { ogółem } \\
\text { (w tys.) }\end{array}$ & $\begin{array}{c}\text { przedprodukcyjnym } \\
\text { (0-17 lat) }\end{array}$ & $\begin{array}{c}\text { produkcyjnym } \\
\text { (18-59/64 lat) }\end{array}$ & $\begin{array}{c}\text { poprodukcyjnym } \\
\text { (60/65 lat) }\end{array}$ & $\begin{array}{c}65 \text { lat } \\
\text { i więcej }\end{array}$ & Kobiet & Mężczyzn \\
\hline 2000 & 38254,0 & 24,4 & 60,8 & 14,8 & 12,4 & 78,0 & 69,7 \\
\hline 2001 & 38242,2 & 23,5 & 61,5 & 15,0 & 12,6 & 78,4 & 70,2 \\
\hline 2002 & 38218,5 & 22,7 & 62,2 & 15,1 & 12,8 & 78,8 & 70,4 \\
\hline 2003 & 38190,6 & 21,9 & 62,9 & 15,2 & 13,0 & 78,9 & 70,5 \\
\hline 2004 & 38173,8 & 21,2 & 63,5 & 15,3 & 13,1 & 79,2 & 70,7 \\
\hline 2005 & 38157,1 & 20,6 & 64,0 & 15,4 & 13,3 & 79,4 & 70,8 \\
\hline 2006 & 38125,5 & 20,2 & 64,2 & 15,7 & 13,4 & 79,6 & 70,9 \\
\hline 2007 & 38115,6 & 19,6 & 64,4 & 16,0 & 13,5 & 79,7 & 71,0 \\
\hline 2008 & 38135,9 & 19,3 & 64,5 & 16,2 & 13,5 & 80,0 & 71,3 \\
\hline 2009 & 38167,3 & 19,0 & 64,5 & 16,5 & 13,5 & 80,1 & 71,5 \\
\hline 2010 & 38529,9 & 18,8 & 64,4 & 16,8 & 13,5 & 80,6 & 72,1 \\
\hline 2011 & 38538,4 & 18,5 & 64,2 & 17,3 & 13,8 & 80,9 & 72,4 \\
\hline 2012 & 38533,3 & 18,3 & 63,9 & 17,8 & 14,2 & 81,0 & 72,7 \\
\hline 2013 & 38495,7 & 18,2 & 63,4 & 18,4 & 14,7 & 81,1 & 73,1 \\
\hline
\end{tabular}

Źródło: Opracowanie własne na podstawie danych z GUS.

Z jednej strony banki mają klientów młodych i perspektywicznych, z drugiej zaś rosnącą grupę starszych klientów, którzy posiadają pewne oszczędności i inwestycje. Każda z tych grup społecznych wymaga innej oferty, innego podejścia, innej reklamy i innej obsługi. Zmiany demograficzne i wydłużający się czas życia wraz z powstawaniem nowych grup społecznych mają zatem niebagatelny wpływ na kształtowanie oferty bankowej, ale także na funkcjonowanie banku, który takie zróżnicowanie oczekiwań musi uwzględniać także w kategoriach wizerunku czy sposobu obsługi, 
- uwarunkowania technologiczne - rozwój technologii komunikacyjnych, rozwój technologii mobilnych, zmiany w modelach wsparcia informatycznego. Rozwój techniki spowodował, że nie sposób prowadzić działalności bankowej bez wykorzystania nowoczesnych rozwiązań komunikacyjnych, informatycznych i technologicznych. Zainteresowanie klientów możliwościami korzystania z najnowszych osiągnięć informatyki, łączności i komunikacji w sposób wyraźny wpłynęło m.in. na konieczność unowocześnienia tradycyjnych usług bankowych i sposobów ich świadczenia oraz na wprowadzenie wielu nowych usług bankowych oraz form kontaktu banku z klientem. Wdrożenie nowoczesnych technologii informatycznych i informacyjnych do rzeczywistości bankowej nie tylko zmieniło relację bank - klient, ale znacząco wpłynęło na sposób organizacji i zarządzania; pozwoliło m.in. na automatyzację działań, skrócenie czasu realizacji czy zmianę pracy placówek bankowych. Dało też szansę na optymalizację kosztową - czy to poprzez łatwiejsze zlecenia realizacji wybranych działań przez podmioty zewnętrzne, czy też poprzez racjonalizację polityki kadrowej,

- uwarunkowania formalno-prawne - zmiany w ustawach podstawowych i wspierających, harmonizacja prawa. Wraz z rozwojem społecznym, gospodarczym i technologicznym również regulacje formalno-prawne podlegają zmianom. Celem tych zmian jest przede wszystkim dopasowanie obowiązujących regulacji prawnych do wymogów zmieniającego się otoczenia, w którym funkcjonują banki. Duże zróżnicowanie oraz zmienność czynników oddziałujących na funkcjonowanie banków powodują konieczność zapewnienia adekwatności i elastyczności rozwiązań prawnych, których celem jest regulacja, uporządkowanie pojawiających się zjawisk, tendencji czy zachowań. Regulacje prawne wybranych aspektów funkcjonowania banku przedstawia tabela 4.

Analiza regulacji formalno-prawnych warunkujących funkcjonowanie banków pozwala dostrzec, iż polskie prawo stopniowo ulega zmianom, których celem jest dostosowanie rozwiązań krajowych do obowiązujących w Europie. Przystąpienie Polski do Unii Europejskiej spowodowało konieczność harmonizacji prawa, czyli dostosowania polskiego prawa do rozwiązań prawnych obowiązujących w Unii, w tym także do przepisów dotyczących instytucji kredytowych. Podstawą dostosowań w obszarze bankowości jest Biała Księga Komisji Europejskiej, w której określone zostały kierunki i zakres harmonizacji prawa państw członkowskich. W tym dokumencie znajdują się zalecenia dotyczące etapowego wdrażania odpowiednich regulacji warunkujących funkcjonowanie efektywnego systemu bankowego. Generalną formą rozpowszechniania norm prawa europejskiego są dyrektywy. Zobowiązują one państwa członkowskie do uzyskania wskazanego w nich stanu prawnego na rynku usług finansowych, za pomocą instrumentów prawnych właściwych danemu systemowi prawa. 
Zasadnicza część standardów europejskich wymienionych w dyrektywach dotyczy norm bezpieczeństwa wykonywania czynności bankowych i nadzoru nad bankami, np. dyrektywy CRD (Capital Requirements Directive).

Tabela 4. Regulacje prawne wybranych aspektów funkcjonowania banku w Polsce

\begin{tabular}{|c|c|}
\hline Aspekt działalności bankowej & Akty prawne \\
\hline Organizacja i zarządzanie bankiem & $\begin{array}{l}\text { Ustawa Prawo bankowe } \\
\text { Ustawa o listach zastawnych i bankach hipotecznych } \\
\text { Ustawa o bankach spółdzielczych, ich zrzeszaniu się i bankach zrzeszających } \\
\text { Ustawa o NBP } \\
\text { Ustawa Kodeks spółek handlowych } \\
\text { Ustawa o nadzorze nad rynkiem kapitałowym } \\
\text { Ustawa o nadzorze nad rynkiem finansowym } \\
\text { Ustawa Kodeks karny }\end{array}$ \\
\hline Zarządzanie finansami banku & $\begin{array}{l}\text { Ustawa Prawo bankowe } \\
\text { Ustawa o przeciwdziałaniu wprowadzaniu do obrotu finansowego wartości } \\
\text { majątkowych pochodzących z nielegalnych lub nieujawnionych źródeł } \\
\text { Ustawa o rachunkowości } \\
\text { Ustawa o biegłych rewidentach i ich samorządzie, podmiotach uprawnionych do } \\
\text { badania sprawozdań finansowych oraz o nadzorze publicznym }\end{array}$ \\
\hline Relacje klienta z bankiem & $\begin{array}{l}\text { Ustawa Prawo bankowe } \\
\text { Ustawa o obrocie instrumentami finansowymi } \\
\text { Ustawa Kodeks cywilny } \\
\text { Ustawa o kredycie konsumenckim } \\
\text { Ustawa Kodeks karny } \\
\text { Ustawa o usługach płatniczych } \\
\text { Ustawa o swobodzie działalności gospodarczej } \\
\text { Rekomendacje Komisji Nadzoru Finansowego }\end{array}$ \\
\hline Zarządzanie ryzykiem & $\begin{array}{l}\text { Ustawa Prawo bankowe } \\
\text { Ustawa o Bankowym Funduszu Gwarancyjnym } \\
\text { Ustawa o NBP } \\
\text { Rekomendacje Komisji Nadzoru Finansowego }\end{array}$ \\
\hline
\end{tabular}

Źródło: Zarzadzanie instytucjami kredytowymi, red. A. Gospodarowicz, A. Nosowski, Wydawnictwo CH Beck, Warszawa 2012, s. 33.

Należy podkreślić, że wszystkie wymienione grupy uwarunkowań zewnętrznych oddziałują wzajemnie na siebie. Zmiany rynkowe wymuszają reakcje regulacyjne, zmiany społeczne wpływają na sytuację ekonomiczną, a postęp technologiczny oddziałuje całościowo. Banki muszą się w tym odnaleźć, a ich sukces zależy od kompetencji w rozpoznawaniu zmian, identyfikacji ich natury, znaczenia i konsekwencji oraz od tego, czy instytucja jest w stanie w miarę elastycznie i adekwatnie modyfikować własne koncepcje czy zachowania biznesowe oraz odpowiadające im rozwiązania organizacyjne ${ }^{10}$. Niezwykle istotne dla działalności banków są również uwarunkowania wewnętrzne, zwane inaczej mikrootoczeniem banku komercyjnego, których analiza przedstawiona została w dalszej części artykułu.

${ }^{10}$ Zarządzanie instytucjami kredytowymi, op.cit., s. 35. 


\section{Główne czynniki i tendencje zmian w mikrootoczeniu banków komercyjnych w Polsce}

Podstawowymi czynnikami kształtującymi mikrootoczenie banku są jego klienci, zarówno deponenci, jak pożyczkobiorcy i kredytobiorcy, oraz jego konkurenci. Deponenci są dla banku dostawcami pieniądza, natomiast pożyczkobiorcy oraz kredytobiorcy są jego odbiorcami. Sprawą kluczową dla kształtowania strategii banku powinna być zatem ocena potencjału reprezentowana przez obie wymienione grupy klientów. W odniesieniu do bankowości detalicznej będą to klienci indywidualni, a miarą ich potencjału będą z jednej strony rozmiary ich środków lokowanych w bankach, z drugiej zaś strony rozmiary zaciąganych kredytów konsumpcyjnych oraz, dodatkowo, stopień nasycenia rynku detalicznego poszczególnymi rodzajami produktów ${ }^{11}$.

Tabela 5. Charakterystyka sektora bankowego w Polsce w latach 2000-2013

\begin{tabular}{|c|c|c|c|c|c|c|}
\hline Rok & $\begin{array}{c}\text { Liczba banków } \\
\text { komercyjnych } \\
\text { prowadzących } \\
\text { działalność } \\
\text { operacyjną }\end{array}$ & $\begin{array}{c}\text { Oddziały } \\
\text { instytucji } \\
\text { kredytowych } \\
\text { (od } 2004 \text { roku) }\end{array}$ & $\begin{array}{c}\text { Sektor } \\
\text { bankowy }\end{array}$ & $\begin{array}{c}\text { Banki } \\
\text { komercyjne } \\
\text { z przewagą } \\
\text { kapitału } \\
\text { państwowego }\end{array}$ & $\begin{array}{c}\text { Banki komercyjne } \\
\text { z przewagą } \\
\text { kapitału } \\
\text { prywatnego } \\
\text { polskiego }\end{array}$ & $\begin{array}{c}\text { Banki komercyjne } \\
\text { z przewagą } \\
\text { kapitału } \\
\text { prywatnego } \\
\text { zagranicznego }\end{array}$ \\
\hline 2000 & 73 & - & 753 & 7 & 20 & 46 \\
\hline 2001 & 69 & - & 711 & 7 & 16 & 46 \\
\hline 2002 & 59 & - & 664 & 7 & 7 & 45 \\
\hline 2003 & 58 & - & 658 & 6 & 6 & 46 \\
\hline 2004 & 54 & 3 & 653 & 5 & 8 & 41 \\
\hline 2005 & 54 & 7 & 649 & 4 & 7 & 43 \\
\hline 2006 & 51 & 12 & 647 & 4 & 7 & 40 \\
\hline 2007 & 50 & 14 & 645 & 4 & 6 & 40 \\
\hline 2008 & 52 & 18 & 649 & 4 & 6 & 42 \\
\hline 2009 & 49 & 18 & 643 & 4 & 6 & 39 \\
\hline 2010 & 49 & 21 & 646 & 4 & 6 & 39 \\
\hline 2011 & 47 & 21 & 642 & 4 & 6 & 37 \\
\hline 2012 & 45 & 25 & 642 & 4 & 5 & 36 \\
\hline 2013 & 41 & 28 & 640 & 4 & 6 & 31 \\
\hline
\end{tabular}

Źródło: Opracowanie własne na podstawie Raportów o Sytuacji Banków sporządzanych przez Urząd Komisji Nadzoru Finansowego w latach 2000-2013.

11 J. Harasim, Zewnętrzne uwarunkowania kształtowania strategii marketingowych banków detalicznych w Polsce - analiza mikrootoczenia, „Bank i Kredyt” wrzesień 2000, s. 47. 
Na podstawie danych zawartych w corocznych Raportach o Sytuacji Banków sporządzanych przez Urząd Komisji Nadzoru Finansowego została przeprowadzona analiza najważniejszych czynników mikrootoczenia banków komercyjnych w Polsce (tabela 5), od roku 2000 do 2013. Raporty zamieszczane są w wersji elektronicznej na stronach internetowych Komisji Nadzoru Finansowego.

Polski sektor bankowy uznawany jest za jeden z najdynamiczniej i najbardziej bezpiecznie rozwijających się sektorów bankowych w Unii Europejskiej. Powodów zmniejszenia się dystansu pomiędzy sektorem bankowym w Polsce a sektorami bankowymi w krajach wyżej rozwiniętych można doszukiwać się nie tylko w słabszej kondycji finansowej banków z innych krajów (np. południowej Europy), które zostały dotknięte kryzysem finansowym, ale również we wnikliwej obserwacji zmian zachodzących na europejskim rynku bankowym ${ }^{12}$. Badanie makro-, jak również mikrootoczenia banków komercyjnych w Polsce stanowi podstawę do przeprowadzenia analizy miejsca polskiego sektora bankowego na tle sektorów innych krajów.

\section{Podsumowanie}

Na kształt współczesnych systemów bankowych niewątpliwie wpływ mają zmiany w preferencjach klientów indywidualnych i instytucjonalnych, do których w warunkach nasilającej się konkurencji banki muszą się bezwzględnie dostosować, zmieniając swoje struktury organizacyjne czy też wchodząc w różnego typu współpracę z innymi bankami oraz z pozabankowymi instytucjami finansowymi. Efektem tego są widoczne, coraz bardziej nasilające się, procesy konsolidacyjne. Działanie wyżej wymienionych grup czynników, zarówno w makro- jak i mikrootoczeniu banków, wpływających na kształt współczesnej bankowości, znajduje odzwierciedlenie w nasilającej się konkurencji w sektorze bankowym, zarówno w skali krajowej, jak i międzynarodowej, ale jednocześnie wyzwala konieczność współdziałania na rzecz stabilności sektora. Główną rolę przypisuje się tu nadzorowi bankowemu, gdyż w tym zakresie mocno akcentowana jest potrzeba współpracy w skali międzynarodowej ${ }^{13}$.

12 B. Lepczyński, M. Penczar, Zmiany w pozycji polskiego sektora bankowego na europejskim rynku depozytowo-kredytowym, w: „Zeszyty Naukowe Uniwersytetu Szczecińskiego” 2014, nr 802; „Finanse, Rynki Finansowe, Ubezpieczenia” 2014, nr 65, red. D. Zarzecki, Wydawnictwo Naukowe Uniwersytetu Szczecińskiego, s. 523-524. 2015

13 System finansowy w Polsce, op.cit., s. 75; Europejska Unia Bankowa, red. M. Zaleska, Difin, Warszawa 


\section{Bibliografia}

Drążek Z., Niemczynowicz B., Zarządzanie strategiczne przedsiębiorstwem, PWE, Warszawa 2003.

Europejska Unia Bankowa, red. M. Zaleska, Difin, Warszawa 2015.

Harasim J., Zewnętrzne uwarunkowania kształtowania strategii marketingowych banków detalicznych w Polsce - analiza mikrootoczenia, „Bank i Kredyt”, wrzesień 2000.

Kałużny R., Ocena funkcjonowania banków w świetle zmieniających się regulacji prawnych, w: „Zeszyty Naukowe Uniwersytetu Szczecińskiego” 2014, nr 802, „Finanse, Rynki Finansowe, Ubezpieczenia” 2014, nr 65, red. D. Zarzecki, Wydawnictwo Naukowe Uniwersytetu Szczecińskiego, Szczecin 2014.

Lepczyński B., Penczar M., Zmiany w pozycji polskiego sektora bankowego na europejskim rynku depozytowo-kredytowym, w: „Zeszyty Naukowe Uniwersytetu Szczecińskiego” 2014, nr 802; „Finanse, Rynki Finansowe, Ubezpieczenia” 2014, nr 65, red. D. Zarzecki, Wydawnictwo Naukowe Uniwersytetu Szczecińskiego, Szczecin 2014.

Romanowska M., Planowanie strategiczne w przedsiębiorstwie, PWE, Warszawa 2009.

Stabryła A., Zarzadzanie strategiczne $w$ teorii i praktyce firmy, Wydawnictwo Naukowe PWN, Warszawa-Kraków 2000.

System finansowy w Polsce, red. Pietrzak B., Polański Z., Woźniak B., Wydawnictwo Naukowe PWN, Warszawa 2003.

Urbanowska-Sojkin E., Banaszak P., Witczak H., Zarządzanie strategiczne przedsiębiorstwem, PWE, Warszawa 2007.

www.knf.gov.pl/o_nas/urzad_komisji

www.nbp.pl

www.stat.gov.pl

Zarządzanie instytucjami kredytowymi, red. M. Gospodarowicz, A. Nosowski, CH Beck, Warszawa 2012.

\section{Main Trends and Factors in Commercial Banks' Micro- and Macroenvironment in Poland}

The text analyses macro- and microenvironment of commercial banks in Poland in order to evaluate their position vis-à-vis banks in other European states. Although Polish banking system is not as developed as the banking systems of other European states, the situation is changing substantially and the differences diminish. 
Keywords: commercial bank, company environment, microenvironment, macroenvironment

\section{Les tendances et facteurs principales du micro- et macro-environnement des banques commerciales en Pologne}

Le texte analyse le micro- et macro-environnement des banques commerciales en Pologne afin d'évaluer leur position vis-à-vis des banques dans d'autres pays européens. Bien que le système bancaire polonais ne soit pas aussi développé que les systèmes bancaires d'autres pays européens, la situation est en train de changer de manière substantielle et les différences en train de diminuer.

Mots-clés: la banque commerciale, l'environnement de l'entreprise, le microenvironnement, le macro-environnement

\section{Микро- и макросреда коммерческих банков в Польше - основные тенденции и факторы}

Окружение коммерческих банков влияет на многие факторы, связанные с их деятельностью на финансовом рынке. В настоящее время одной из важнейших тенденций является глобализация, которая влечет за собой, среди прочего, снижение различий в развитии банковских секторов в Европейском союзе. Банковская система в Польше до сих пор не так хорошо развита, как в других европейских странах, но этот разрыв в последние годы уменьшился. Определение места банковского сектора в Польше, по сравнению с банковскими секторами в более развитых странах, не было бы возможным без комплексного анализа макро- и микросреды коммерческих банков в Польше.

Ключевые слова: коммерческий банк, окружающая среда предприятия, микросреда, макросреда 
